\title{
Physical Education and health: perspectives for high school
}

\author{
I 1 Juliana Rocha Adelino Dias, ${ }^{2}$ Adalberto dos Santos Souza, \\ ${ }^{3}$ Rogério Cruz de Oliveira I
}

Abstract: This study aims to discuss the perspectives of Physical Education for high school regarding health. To this end, a literature review was developed, and a pedagogical work proposal was presented. The literature review sought theoretical subsidies, especially in documents that guide the practice of physical education in school environments, whereas the proposal was constructed from the dialectical pairs presented by Luiz Carlos Freitas (objectives $\mathrm{x}$ evaluation and content $\mathrm{x}$ methodology). In this study, a proposal was made so that Physical Education can contribute to the training of critical and independent subjects in relation to the opinions they assume. We believe that this proposition can encourage students to reflect on the body and health regarding contemporary precepts of the active and healthy lifestyle, providing an expanded look at body practices and life.

> Keywords: Physical Education; school; body; health.

\author{
1 Universidade Federal de São \\ Paulo. Santos-SP, Brasil (juliana \\ dias@icloud.com). \\ ORCID: 0000-0002-0674-7813 \\ ${ }^{2}$ Universidade Federal de São \\ Paulo. Guarulhos-SP, Brasil \\ (neysouza11@hotmail.com). \\ ORCID: 0000-0003-3782-6298 \\ ${ }^{3}$ Universidade Federal de São \\ Paulo. Santos-SP, Brasil (rogerio. \\ unifesp@gmail.com). \\ ORCID: 0000-0002-8615-0397
}

Recebido em: 15/06/2020 Aprovado em: 14/07/2020 Revisado em: 10/09/2020 


\section{Introduction}

Recent decades have seen a growing movement for well-being, health promotion and quality of life in several sectors of society. In Brazil, the creation of the Programa Academia de Sauide [Health Gym Program] can be mentioned, which is responsible for creating spaces of body practices ${ }^{1}$ in cities.

Globally, the World Health Organization (WHO) proposed, in 2004, the Global Strategy for Diet, Physical Activity and Health as an instrument for general health promotion for populations and individuals, and prevention of the growth of chronic non-communicable diseases worldwide. Regarding body practices, the actions cover the basic health network and the community providing actions of counseling and dissemination; intersectoriality and mobilization of partners; and monitoring and evaluation (WHO, 2004).

The model of "Schools Promoting Health" emerges within this context, seeking to encompass some of the principles and methods established in the Global Health Promotion Conferences in school environments. Thus, the "Health Promoting School" emerges as a possible strategy to promote quality of life and health, hoping that the school will develop activities that favor health and the teaching of life skills, so students can acquire knowledge about the adoption and maintenance of healthy behaviors and lifestyles. Another raised point refers to the structure created to foster healthy environments and improve the quality of life at school and in its vicinity. In the meantime, the model created should also seek to strengthen the links between health and education services to promote the integration of health, diet, nutrition, leisure, physical activity and professional training (OMS, 2006).

Although one could support the criticism that the strand that considers that the adoption of healthy lifestyles by individuals is a fallacy, because according to Castiel (2003), in contexts of poverty and social vulnerability people do not choose lifestyles but trace survival strategies, one cannot deny that this is a potentiating initiative of intersectoral actions between education and health. Considering Savianni's (2003) perspective, more than an institution of socialization of scientific knowledge, the school is a sociocultural space where people, projects and learning intersect (GUSMÃO, 2003; DAYRELL, 1996; FORQUIN, 1993). So, why not a space that discusses health? 
Considering the discussion above, observing health in the school context becomes pertinent, which, in the case of physical education, goes through issues related to health promotion. Although it is not an unprecedented and recent issue for physical education to discuss health ${ }^{2}$ in the school context, the contemporary context is favorable to deepen the theme, given the media flood that exhibits models of healthy bodies at the expense of a discourse of causality between body practices and health, already refuted by Palma, Bagrichevsky and Estevão (2003).

This study thus aims to discuss the perspectives of physical education for high school with regard to health. The objective is to shed light on a theme privileged by contemporary public policies but that does not seem to find echo in the field of education since - rather than valuing physical education as a relevant curricular component - the Brazilian high school reform relegated the theme to a lower plan, that of studies and practices.

Thus, considering that health in the context of school physical education has occupied a place of little value (ORFEI; TAVARES, 2009), and that the production of knowledge in physical education in the 1980s did not absorb public health movements (BAGRICHEVSKY; ESTEVÃO, 2008), we believe that physical education has things to say.

\section{Physical Education in high school}

To realize that school physical education has fundamental importance in the lives of young individuals and as stated earlier, something to be said is to perceive the place that physical education classes hold in high school. This requires an understanding of the relationship of its contents with the interests of students at this school stage, since its legitimation will not occur in terms of contents for university entrance examination $s^{3}$ - as is common in other areas -; thus, attributing meaning to it. On the contrary, it is the relationship of these contents with the lives of students that will attribute meaning to the class, make it alive, engaging and pulsating (SOUZA, 2008).

Before addressing the central issue of this study - i.e., the interface between physical education and health, and its perspectives for high school -, we must start from how this discussion should be present at this school stage. Betti and Zuliani 
(2002, p. 76) argue that physical education in high school should be seen differently from elementary school. For them, these classes

[...] must present its own innovative characteristics that consider the new cognitive and affective-social phase reached by adolescents. This duty does not imply losing sight of the purpose of integrating the student into the body culture of movement. On the contrary, in high school one can provide the student with the enjoyment of this culture through the practices that such student identifies as significant for himself/herself.

One of the tasks currently defended by the area is to provide meaningful practices for students that are not bound to the idea of merely doing something to do it, but with the contribution to the training of students who are autonomous, cooperative and able to question and criticize the values transmitted to them. The need for the school to organize the reconstruction of school knowledge with the elements of human subjectivity and self-initiative is, according to Franco and Novaes (2001, p. 181), "a way of organizing school and everyday life, promoting the training of a conscious citizen who is historically engaged in the problems of his time, a dynamic and participatory individual."

Such need to structure school and the daily life of students is precisely what physical education must guide in its content so that, with this, the understanding of the meanings attributed by young people to the classes represent something for them. Given this understanding, the objectives of physical education in high school can follow the path that contributes so that students can overcome the hegemonic view, that is, of sports, dances, martial arts, gymnastics and physical exercises as products of consumption, dictating the model to be followed.

This new historical context imputes physical education a review of its practice, and this perception is important because the teacher, when working with people who are affected, at the same time, by a general culture and a school culture, must consider this aspect. Understanding what occurs in general and school cultures allows one to infer about how comprehending what occurs in the school universe is closely linked to the interests outlined outside this social space.

This thought leads us to think of school as a space of social representation that exists independent of the subject's individuality, given that this environment is permeated by collective representations. We must stress that, although we propose a mediation between the knowledge brought by students and the one systematized by a given group, this does not mean the abandonment of the existing knowledge 
developed for decades by the area; what we propose is to give life to them, to historically contextualize them. To historically think about school is to think of it as a sociocultural environment, which for Dayrell (1996, p. 136), implies in:

Understanding it from the perspective of culture under a denser look that considers the
dynamism of everyday doing performed by men and women, workers, black and white
individuals, adults and adolescents, and finally, students and teachers - concrete human
beings who are social and historical subjects, present in history, actors in it. Discussing
school as a sociocultural environment thus implies rescuing the role of subjects in the
social fabric that constitutes it as an institution.

Regarding physical education classes, rescuing the role of the subjects would thus go through the relationship established with knowledge and, in this sense, the discussion about the interfaces between physical education and health is adapted in an essential manner, given that addressing the aspects related to health disconnected from fads and media patterns provides a gain in the quality of a discussion that envisions new horizons.

Sports, dances, martial arts, gymnastics and physical exercises are known to increasingly face the transition into consumer products and objects of widely divulged information to the general public. Moreover, young people are bombarded daily by images and enunciates that propose a pattern of body beauty to be achieved by all. Contrary to this, a small portion of the population systematically practices sports and physical exercises, and the lifestyle generated by new socioeconomic conditions favors sedentary lifestyles and the movement towards private or semiprivate spaces.

It is in this sense that physical education in high school - the conclusive stage of basic education - should provide students with the expansion and improvement of their cognitive, motor, affective and social repertoire, enabling the appropriation of the critical observation of body culture, so they can claim participation and protagonism in their production, reproduction, enjoyment, and transformation.

The body is the main consumer of the beauty and health industries nowadays, thus making the ambiguity about the knowledge of the body a trace of contemporary culture. The human need to fit aesthetic patterns can trigger an image of crisis whether it is at the foundations of our culture or even the very individual crisis -, creating an internal struggle between the representations of the body we have and the body we want. This situation causes the concepts about health to be intentionally 
distorted and linked to aesthetic ones, and the public that suffers the most from this bombardment of misguided information are young people.

The patterns are disseminated by the most diverse media, and predefined models reinforce antagonistic views, e.g., between youth and old age, activity and passivity, among others. Given this context, the biological cycle is not the only aspect highlighted because the body takes on a symbolic connotation that results from social constructions, whose ideal image is that of health and beauty associated with youth.

Discussions about diseases related to sedentary lifestyles, the role of media in the construction of body beauty patterns, the various meanings attributed to the body, the relationship between physical exercise and health and sexual roles related to expectations of physical and sports performance, among others, are often excluded from the contents of physical education classes in high school, and with this, young individuals build misguided meanings about these questions - which can be damaging to their own health.

\section{Physical Education and health at school}

Since school is an institution that accommodates a considerable portion of young individuals in Brazil, its duty goes beyond educating only about the contents taught in traditional disciplines, as stated by Pimenta (1993), and Dourado and Oliveira (2009), when referring to the training of critical students. Thus, the school must conceive, from a critical perspective, humans in their completeness: a being formed by biological, material, affective, aesthetic, and playful dimensions (DOURADO; OLIVEIRA, 2009).

Health emerges as a privileged cross-sectional topic in this interim, and when considering physical education as a curricular component, its efforts are focused on health promotion. From the understanding of health as a result of living conditions, work, education, housing, leisure, among other (BRASIL, 1986) as an experimentation of the individual in its relationship with society (PALMA; ESTEVÃO; BAGRICHEVSKY, 2003), one can understand the health promotion from Czeresnia (1999) as a set strategies involving people's individual and collective capacities to deal with the multiple health constraints. For the author, health promotion is a concept that strengthens health by constructing the individuals' the ability to choose, and by empowering them to pay attention to differences, as shown below: 
[...] strengthening individual and collective capacity to deal with the multiplicity of factors that condition health. Promotion goes beyond applying techniques and norms [...] It has to do with strengthening health by building a capacity for choice, using knowledge to discern differences between (and singularities in) events (CZERESNIA, 1999, p. 706).

That is, from the perspective that Castiel and Silva (2006) call 'libertarian', which seeks social change from the perspective of popular education proposals, and in physical education this is consistent with critical teaching approaches, e.g. the critical overcoming (SOARES et al., 1992) and the critical emancipatory (KUNZ, 1994). From this point of view, we can understand physical education in the school context "[...] as a vehicle for health promotion, mediated by a contemporary view of health and its relationship with physical activities" (DEVIDE, 1996, p. 52).

[...] health becomes a pedagogical issue in a more genuine way, strengthening the idea that the participation of school physical education would be linked to the notion of a health education (rather than directly promoting health) (BRACHT, 2013, p. 181).

This means refuting the common understanding that the single role of physical education is to provide body practices so students can live well and be healthy. Or, from Santos and Costa's (2017) perspective, to distance oneself from the contemporary scientific paradigm that considers that body practices serve to acquire and maintain health. Considering physical education as the curricular component whose teaching topic is body culture, ${ }^{4}$ we corroborate Bracht $(2013$, p. 187) in the statement that health would not be a content of physical education, but a horizon to be pursued by the pedagogical project of the discipline when put into action: "[...] the health effect would be implicit in the contribution that school PE [physical education] could provide, from the mediation of different body practices, to the integral education of the individual".

This perspective is also expressed in the Brazilian National Curriculum Parameters (PCN):

A Physical Education attentive to the problems of the present cannot fail to elect, as one
of its central guidelines, that of health education. Physical Education intends to provide
services of social education to students, contributing to a productive, creative and suc-
cessful life. Physical Education finds, in the orientation by health education, a means of
achieving its objectives (BRASIL, 1999, p. 156).

According to Almeida, Oliveira and Bracht (2016, p. 91), the PCN approach is relevant for physical education since it implies a broader linkage process with 
health, distancing itself from "[...] the idea of health as the absence of illnesses, and of physical activity as a synonym for health."

Pedagogical practices in physical education must be able to, corroborating (MOLINA NETO et al., 2017, p. 99), select, plan and put into practice "[...] body experiences that go beyond school life, educating for health in adulthood with quality, and for the exercise of leisure conscious of social, political, economic, and cultural conditions that involve free time and its use". Therefore, within a context of critical training, physical education must provide tools to contribute to the integral training of this student, consistent with ethical, aesthetic and health-related values, not prioritizing only physical fitness - which has historically privileged a Cartesian dialogue with the students' body experiences.

Given this discussion, we understand that physical education in high school holds an imminent potential with the development of the health theme since classes traditionally occur with a bias towards sports (SANTOS; COSTA, 2017); thus, lacking in the attribution of new meanings. This is the time to deepen the systematization of knowledge of body culture (SOARES et al., 1992).

In Araújo and Grunennvaldt (2017), who investigated high school students from a public school in Mato Grosso (a middle-western state of Brazil), $85 \%$ of volunteers recognize school physical education as necessary for their education and highlighted health-related aspects as the main elements of this discipline, especially

[...] the acquisition of habits considered healthy in contrast to a sedentary life, attitudes of an active life; definition for the practice of physical exercises and sports, behaviors and information about food and other statements involving health (ARAÚJO; GRUNENNVALDT, 2017, p. 262).

Considering the discussion above, we will now focus on elucidating perspectives of health approach to physical education in high school, understanding, from Santos and Costa (2017), the urgent need to resist to the strict contemporary enunciates that permeate body practices. Aligned with Almeida, Oliveira and Bracht (2015, p. 91), the challenge is to discuss the contributions that physical education can provide "for a 'health training' in school," in the case of this study, high school. ${ }^{5}$

\section{Physical Education and health: perspectives for high school}

We can affirm that physical education is crucial to high school by providing students with the opportunity to reflect on and understand the various spheres 
surrounding body practices, thus filling the knowledge gap that other curricular components do not cover in terms of pedagogical practice. Regarding health, our understanding is that the debate on the body takes on a central role, corroborating Carrano's (2011) arguments, for whom it is pertinent to bring the subject to the center of school practices. For Santos and Costa (2017), contemporary health discourses involve the body and are close to physical education classes. In particular, the proposal existing in the Brazilian National Common Curricular Base (BNCC) highlights that physical education in high school must contemplate contemporary themes of the daily lives of young people to consider "their physical, psychoemotional and social dimensions, in order to develop and disseminate actions to prevent and promote health and well-being" (BRASIL, 2017, p. 543). Thus, addressing issues related to body care, beauty and aesthetics in physical education in high school is pertinent, especially in Dias's (2013) horizon, for whom the reflections should involve current body standards.

For Ludorf(2009), physical education classes, in their daily practice, can contribute to the formation of sociocultural, subjective, and political values. Therefore, it is possible to foster an environment for the critical training of students in their process of learning, becoming conscious, and acquiring knowledge and experiences for life, respecting the differences, their own body and the body of others since, currently, one of the most relevant aspects regarding the body is appearance.

Nowadays, body models on which people can mirror their own circulate in the various media available, serving as parameters to be pursued. For Lovisolo (2006), this perspective approaches the model called JUBESA (youth, beauty and health; in Portuguese: juventude, beleza e saúde), that incites the search for body transformations that result in young and beautiful results, which end up being confused with health itself. Consequently, bringing into the existence a body pattern that, for most people, is unattainable. We observe that the dissemination of an ideal of beauty associated with an aesthetic relationship exists and, in this scenario, physical attributes become crucial in the composition of beauty. We must note that beauty in our society is associated with a good image and success, and to be beautiful one must have a young, athletic, healthy and active appearance, among other attributes (OLIVEIRA; OLIVEIRA, 2013). Also, there is a new social paradigm, in which there is a moral duty to be beautiful (NOVAES, 2010), at any stage of life since it is never late to start having a more active lifestyle (LOVISOLO, 2006). 
There is no room for other body shapes in this environment, pressuring young individuals to repudiate obesity, sedentary lifestyles, physical inactivity, etc. "That is, today's gaze on what is wrinkled, and fat responds to moral, rigid and relentless commands that validate only what is smooth and young" (SANTOS; COSTA, 2017, p. 4). For Fraga (2006), this movement allows the creation of new marginal identities, especially about the concept of being sedentary and fat.

Given this context, the idea of a standard body seems to be far from the reality of all because, according to Oliveira and Oliveira (2013, p. 1), contemporary body patterns are so rigid that it is virtually impossible to fit in. "If you're fat, you must become thin; if you are thin, you must become strong; if you are strong, you must have the most defined musculature, and so on"; generating high rates of body dissatisfaction. For Dias (2013), these and other related issues reflect on the life of adolescents at school.

Nóbrega (2000) warns for the need to consider the complexity of human beings in the pedagogical practices of physical education because when intervening about the body and movement, issues that go beyond motor and organic capacities surface; issues related to well-being and health present the possibility of overcoming the reductionism of the body-object.

Thus, the physical education teacher is responsible for directing an intervention that, from Molina Neto's et al. (2017) perspective, considers health education in all its dimensions in favor of broadening cultural, ethical, aesthetic and moral horizons. However, the authors warn us of the need for:

[...] our [Physical Education] classes to accomplish these purposes, and that, at the end of each class, we can have an affirmative, concrete and specific answer to the question: what did we learn in today's class? And that, at the end of each school quarter, students and teachers can evaluate the effects of this learning and evaluate themselves with the seriousness that a Curricular Component requires (p. 102).

In this context, we resort to Bracht (1997), for whom any pedagogical theory and physical education practice must answer two questions: why (the meaning) and how (instrumental). That is, a pedagogical practice of physical education in high school focused on health must state its objectives, the knowledge addressed, the teaching methods, and how the evaluation is made. And it is from these four dimensions of pedagogical practice, that Freitas (1995) understands as dialectical pairs (objectives $\mathrm{x}$ evaluation and content $\mathrm{x}$ methodology), which we showed in chart 1 . 
Chart 1. Perspectives to the Physical Education and health in high school*

\begin{tabular}{|c|c|c|c|c|}
\hline & Objective & Content & Method & Evaluation \\
\hline $\begin{array}{c}11^{\circ} \\
\text { year }\end{array}$ & $\begin{array}{l}\text {-To understand the } \\
\text { relationship between } \\
\text { the body, health and } \\
\text { body practices }\end{array}$ & $\begin{array}{c}\text {-Body and health } \\
\text {-Different types of } \\
\text { body practices }\end{array}$ & $\begin{array}{c}\text {-Expositive classes } \\
\text {-Body } \\
\text { experimentation } \\
\text { classes }\end{array}$ & $\begin{array}{c}\text { Criteria: } \\
\text {-Qualitative leap } \\
\text {-Body availability } \\
\frac{\text { Instruments: }}{\text {-Tests }} \\
\text {-Workshops }\end{array}$ \\
\hline $\begin{array}{l}22^{\circ} \\
\text { year }\end{array}$ & $\begin{array}{l}\text {-To understand } \\
\text { the different types } \\
\text { of practices and } \\
\text { their possible } \\
\text { relationships with } \\
\text { the production of } \\
\text { health }\end{array}$ & $\begin{array}{c}\text {-Effects of body } \\
\text { practices on people's } \\
\text { health }\end{array}$ & $\begin{array}{l}\text {-Expositive classes } \\
\text {-Body } \\
\text { experimentation } \\
\text { classes } \\
\text {-Work with the } \\
\text { school community }\end{array}$ & $\begin{array}{c}\text { Criteria: } \\
\text {-Qualitative leap } \\
\text {-Body availability } \\
\text { Instruments: } \\
\text {-Project } \\
\text { development for } \\
\text { school community } \\
\text { diagnosis }\end{array}$ \\
\hline $\begin{array}{l}33^{\circ} \\
\text { year }\end{array}$ & $\begin{array}{l}\text {-To understand the } \\
\text { impact of bodily } \\
\text { practices on people's } \\
\text { lives }\end{array}$ & $\begin{array}{c}\text {-Body practices and } \\
\text { life } \\
\text {-Doping }\end{array}$ & $\begin{array}{l}\text {-Expositive classes } \\
\text {-Body } \\
\text { experimentation } \\
\text { classes } \\
\text {-Work with the } \\
\text { school community }\end{array}$ & $\begin{array}{c}\text { Criteria: } \\
\text {-Qualitative leap } \\
\text {-Body availability } \\
\text { Instruments: } \\
\text {-Project elaboration } \\
\text { for intervention } \\
\text { in the school } \\
\text { community }\end{array}$ \\
\hline
\end{tabular}

Reference: The authors.

*This perspectives are inspired/based in some proposals or considerations presents in specific publications from Physical Education field, namely: Soares et al. (1992); Kunz (1994); Bracht (2013), and; Devide (1996; 2002; 2003). Moreover, it should be regarded as a cross-cutting theme from the body culture.

However, these perspectives should be faced as an example, because should be comprehended side by side with local demands and needs from students, parents, school managers, and other community members. Otherwise, it may not overcome the traditional limits from the field, e.g.: "exercise is health"; "mens sana in corpore sano"; "no pain, no gain"; and others linking by active life style. In Freire's perspectives, the pedagogical practices should be engaged with social transformation (CECCIM, 2007). For Physical Education at high school, it means going beyond exercising, and, in according to Kunz (2007), the health risk factors.

Besides that, we can recognize that when considering the binomial physical education and health and observing the dialectical pairs, as presented in chart 1 , 
students may be encouraged to reflect on body and health with regard to contemporary enunciates of active and healthy lifestyles, providing an expanded look at body practices and life. This would contribute to the training of a conscious student who is capable of critically positioning himself/herself in the face of the new forms of body culture. Therefore, the production of a positive effect with the curricular themes related to health can be constructed from the moment that the purposes of what to teach and how to teach have been exposed, with the objectives being clearly presented and developed in physical education classes in high school.

We can observe in the PCN and BNCC regarding high school the existence of a direction to the practice of physical education in high school that contemplates a broad perspective of health. However, the physical education teacher has autonomy to select the contents and perform a dynamic planning that meets the needs and desires of students when facing reality. Prioritizing, as presented in the BNCC, the need to "know the self, appreciate the self and take care of one's own physical and emotional health, understanding the self in human diversity and recognizing one's own emotions and those of others, with self-criticism and the ability to deal with them" (BRASIL, 2017, p. 10).

\section{Final considerations}

To discuss and present possibilities in physical education in high school, while also observing the concept of health, are practices that have always been present in the history of this discipline. However, we can observe that despite discussions on body issues linked to a broad perspective in health are not new, this is a theme that still requires reflection. Considering the complexity that surrounds the topic, this study highlighted the constant exposure in the media and the spread in society of healthy lifestyles that are presented as unquestionable. We thus believe that physical education, especially in high school, can have a pedagogical practice in its scope that contemplates themes related to health and that enables students, from body practices, to deepen the knowledge of the subject and thus contribute to the role of trainer of critical and independent subjects in relation to the opinions they assume.

Therefore, we believe that the contents that can and must be discussed on these classes must be clearly defined. Since there is no defined curriculum for the discipline and the teacher is the one responsible for selecting the contents and performing a 
dynamic planning that meets the needs and desires of students in the face of the reality of aspects related to the body in contemporaneity, its consequences, and effects on health. Similarly to what we can observe in the guidelines that govern the discipline - i.e., PCN and BNCC -, the student must be trained in an integral way, going beyond the training that focuses on the biological and/or technical dimension as we usually observe in the field of physical education. ${ }^{6}$

\section{References}

ALMEIDA, U. R.; OLIVEIRA, V. J. M.; BRACHT, V. Educação física escolar e o trato didático-pedagógico da saúde: desafios e perspectivas. In: WACHS, F.; ALMEIDA, U.R.; BRANDÃO, F.F.F. (Orgs.). Educação física e saúde coletiva: cenários, experiências e artefatos culturais. Porto Alegre: Rede Unida, 2016. p.87-112.

ARAUJO, G. F.; GRUNENNVALDT, J. T. A educaçấo física e as finalidades educacionais do ensino médio: um estudo de caso. Motrivivência, v. 29, n. 51, p. 251-269, 2017.

BAGRICHEVSKY, M.; ESTEVĀO, A. Perspectivas para a formação profissional em Educação Física: o SUS como horizonte de atuação. Arquivos em Movimento, v. 4, n. 1, p. 128-143, 2008.

BELTRÃO, J. A. A educação física na escola do vestibular: as possíveis implicaçôes do ENEM. Movimento, v. 20, n. 2, p. 819-840, 2014.

BETTI, M.; ZULIANI, L. R. Educação Física escolar: uma proposta de diretrizes pedagógicas. Revista Mackenzie de Educação Física e Esporte, n. 1, p. 73-81, 2002.

BRACHT, V. Educação Física \& Saúde Coletiva: reflexôes pedagógicas. In: FRAGA, A. B.; CARVALHO, Y. M.; GOMES, I. M. (Org.). As práticas corporais no campo da saúde. São Paulo: Hucitec, 2013, v. 1, p. 178-197.

. Educação Física e aprendizagem social. 2.ed. Porto Alegre: Magister.

BRASIL. Casa Civil. Subchefia para Assuntos Jurídicos. Lei no 10.328, 12 dez. 2001. Diário Oficial da República Federativa do Brasil. Poder Executivo, Brasília, DF, 13 dez. 2001.

. Conferência Nacional de Saúde, VIII, 1986. Brasília. Relatório Final. Brasília: Ministério da Saúde, 1986.

. Ministério da Educação. Base Nacional Comum Curricular-BNCC, versão aprovada pelo CNE, novembro de 2017.

. Ministério da Educação. Secretaria da Educação Média e Tecnológica. Parâmetros

Curriculares Nacionais: Ensino Médio / Ministério da Educação. Secretaria de Educaçấo Média e Tecnológica / Brasília: Ministério da Educação, 1999. 
CARRANO, P. Identidades culturais e escolas: arenas de conflitos e possibilidades. In: MOREIRA, A.F.B.; CANDAU, V.M. (Orgs.). Mutliculturalismo: diferenças culturais e práticas pedagógicas. 7.ed. Petrópolis: Vozes, 2011. p. 182- 211.

CASTIEL, L. D.; SILVA, P. R. V. A noção “estilo de vida” em promoção da saúde: um exercício crítico de sensibilidade epistemológica. In: BAGRICHEVSKY, M. et al. (Orgs.). A saúde em debate na Educação Física - volume 2. Blumenau: Nova Letra, 2006. p.67-92.

CECCIM, R. B. Pacientes impacientes: Paulo Freire. In: BRASIL. Ministério da Saúde. Secretaria de Gestão Estratégia e Participativa. Departamento de Apoio à Gestão Participativa. Caderno de Educação Popular e Saúde. Brasília: Ministério da Saúde, 2007. p.32-45.

CZERESNIA, D. The concept of health and the difference between prevention and promotion. Cadernos de Saúde Pública, v. 15, n. 4, p. 701-709, 1999.

DAYRELL, J. A escola como espaço sócio-cultural. In: DAYRELL, J. (Org.). Múltiplos olhares sobre educação e cultura. Belo Horizonte: UFMG, 1996. p. 136-161.

DEVIDE, F. P. A educação física escolar como via de educação para a saúde. In: BAGRICHEVSKY, M.; ESTEVÃO, A.; PALMA, A. (Orgs). A saúde em debate na educação física. Blumenau: Edibes, 2003, p. 137-150.

. Educação Física e saúde: em busca de uma reorientação para a sua práxis. Movimento, v. 3, n. 5, p. 44-55, 2007.

. Educação Física e Saúde: em busca de uma reorientação para sua práxis. Movimento, v.5, n.2, p.44-55, 1996.

. Educação Física, Qualidade de Vida e Saúde: campos de intersecção e reflexôes sobre a intervenção. Movimento, v. 8, n. 2, p. 77-84, 2002.

DIAS, J. R. A. Culturas escolares e adolescentes: Imagem corporal e relaçôes sociais. 2013. $222 \mathrm{f}$. Dissertação (Mestrado em Educação) - Universidade Católica de Santos, Santos, 2013.

DOURADO, L. F.; OLIVEIRA, J. F. A qualidade da educação: perspectivas e desafios. Caderno CEDES, v. 29, n. 78, p. 201-215, 2009.

FORQUIN, J. C. Escola e cultura: as bases sociais e epistemológicas do conhecimento escolar. Porto Alegre: Artmed, 1993.

FRAGA, A. B. Promoção da vida ativa: nova ordem físico-sanitária na educação dos corpos contemporâneos. In: BAGRICHEVSKY, M. et al. (Orgs.). A saúde em debate na educação física - volume 2. Blumenau: Nova Letra, 2006. p.105-118.

FRANCO, M. L. P. B.; NOVAES, G. T. F. Os jovens do ensino médio e suas representações sociais. Cadernos de Pesquisa, n. 112, p. 167-183, 2001. 
FREITAS, L. C. Crítica da organização do trabalho pedagógico e da didática. Campinas: Papirus, 1995.

GUSMÃO, N. M. M. Os desafios da diversidade na escola. In: (Org.). Diversidade, cultura e educação: olhares cruzados. São Paulo: Biruta, 2003, p. 83-106.

KUNZ, E. Ministério da saúde adverte: viver é prejudicial à saúde. BAGRICHEVSKY, M.; ESTEVÃO, A.; PALMA, A. (Orgs.). A saúde em debate na educação física. v. 3. Ilhéus: UESC, 2007. p.173-186.

KUNZ, E. Transformação didático-pedagógica do esporte. Ijuí: Unijuí, 1994.

LAZZAROTTI FILHO, A. et al. O termo práticas corporais na literatura científica brasileira e sua repercussão no campo da Educação Física. Movimento, v. 16, n. 1, p. 11-29, 2010.

LOVISOLO, H. Em defesa do modelo JUBESA (juventude, beleza e saúde). In: BAGRICHEVSKY, M. et al. (Orgs.). A saúde em debate na Educação Física. v. 2. Blumenau: Nova Letra, 2006. p. 157-178.

LUDORF, S. M. A. Corpo e formação de professores de educação física. Interface, v. 13, n. 28, p. 99-110, 2009.

MOLINA NETO, V. et al. A Educação Física no Ensino Médio ou para entender a Era do Gelo. Motrivivência, v. 29, n. 52, p. 87-105, 2017.

NÓBREGA, T.P. Corporeidade e Educação Física do corpo-objeto ao corpo-sujeito. 2.ed. Natal: EDUFRN, 2000.

NOVAES, J.V. Com que corpo eu vou? Sociabilidade e uso do corpo nas mulheres das camadas altas e populares. Rio de Janeiro: PUC-RJ, 2010.

OLIVEIRA, F.; OLIVEIRA, R.C. O culto ao corpo e seus desdobramentos contemporâneos. Lecturas, Educación Fisica y Deportes, v. 18, n. 185, p. 1-1, 2013.

ORFEI, J. M.; TAVARES, V. P. Promoção da Saúde na Escola Através das Aulas de Educação Física. In: BOCCALETTO, E. M. A.; MENDES, R. T. (Orgs.). Alimentação, Atividade Física e Qualidade de Vida dos Escolares do Município de Vinhedo-SP. Campinas: IPES Editorial, 2009. p. 81-87.

ORGANIZACIÓN PANAMERICANA DE LA SALUD. Memoria de la Cuarta Reunión de la Red Latinoamericana de Escuelas Promotoras de la Salud. Serie Promoción de la Salud. Washington, n. 11, p. 214-218, 2006.

PALMA, A.; BAGRICHEVSKY, M.; ESTEVÃO, A. Análise sobre os limites de inferência causal no contexto investigativo sobre "exercício físico e saúde". In: BAGRICHEVSKY, M.; PALMA, A.; ESTEVÃO, A. (Orgs.) A saúde em debate na Educação Física. v. 1. Blumenau: Edibes, 2003. p. 33-52. 
PIMENTA, S. G. Questôes sobre a organização do trabalho na escola. São Paulo: FDE, 1993.

SANTOS, A. M.; COSTA, F. S. Filosofia da Corporeidade: transversalizaçóes de um corpo intenso de devir. Educação e Realidade, v. 43, n. 1, p. 223-237, 2018.

SAVIANI, D. Pedagogia histórico-crítica. 8.ed. Campinas: Autores Associados, 2003.

SOARES, C. L. et al. Metodologia do Ensino de Educação Física. São Paulo: Cortez, 1992.

SOUZA, A. S. Educação Física no Ensino Médio: Representaçôes dos Alunos. 148p. 2008. Tese

(Doutorado em Educação Física) - Faculdade de Educação Física, Universidade Estadual de Campinas, 2008.

WORLD HEALTH ORGANIZATION (WHO). Estratégia global em alimentação saudável, atividade física e saúde. Genebra: WHO, 2004.

\section{Notas}

${ }^{1}$ In this study we will adopt the term "body practices" according to Lazzarotti Filho et al. (2010), for who such practices are a part of the culture linked to human movement. In our understanding, the expression "body practices" is more comprehensive than physical activity and physical exercise.

2 According to Soares et al. (1992), the knowledge of body culture has interdependence with sociopolitical problems such as ecology, work relationships, social prejudices, poor income distribution, and with health.

${ }^{3}$ Nowadays, Physical Education' contents are presented in the "High School National Exam" (ENEM - "Exame Nacional do Ensino Médio"). In this sense, Beltrão (2014) stresses that this fact can means the Physical Education at school' valorization or its standardization by the conceptual dimension, in detriment to body experiences. Also, the knowledges of body and health.

${ }^{4}$ The expression body culture was coined in the work Metodologia do Ensino da Educação Física (SOARES et al., 1992) and covers the historically accumulated knowledge of body practices capable of organization and systematization in school contexts, namely: playful activities, gymnastics, dance, martial arts, sports. However, other denominations coexist and are must be cited such as movement culture, physical culture, body culture of movement, among others. For more on this subject, refer to Daolio (2004).

${ }^{5}$ In the study of Almeida, Oliveira e Bracht (2016), the contributions concern the context of elementary school.

${ }^{6}$ J. R. A. Dias trabalhou na concepção do trabalho, argumentação teórica, redação, revisão e aprovação da versão final a ser submetida. A. dos S. Souza trabalhou na argumentação teórica, redação, revisão e aprovação da versão final a ser submetida. R. C. de Oliveira trabalhou em todas as etapas do manuscrito, desde sua concepção, redação, revisão e aprovação da versão final a ser submetida. 


\section{Resumo}

\section{Educação Física e saúde: perspectivas para o ensino médio}

Este estudo tem o objetivo de discutir as perspectivas da educação física para o ensino médio no que se refere à saúde. Para tanto, foi desenvolvida uma revisão de literatura e apresentação de uma proposta pedagógica de trabalho. A revisão de literatura buscou subsídios teóricos, sobretudo, nos documentos que norteiam a prática da educaçáo física em âmbito escolar, enquanto que a proposta foi construída a partir dos pares dialéticos apresentados por Luiz Carlos Freitas (objetivos $\mathrm{x}$ avaliação e conteúdo $\mathrm{x}$ metodologia). Neste estudo, foi realizada uma proposta para que a educação física possa contribuir na formaçáo de sujeitos críticos e independentes com relação às opiniōes que assumem. Acreditamos que a proposição realizada pode incentivar os alunos a refletirem sobre o corpo e a saúde no que se refere aos ditames contemporâneos do estilo de vida ativo e saudável, proporcionando um olhar ampliado sobre as práticas corporais e a vida.

Palavras-chave: Educação física; escola; corpo; saúde. 